\title{
Inferring the Subsurface Basement Depth and the Contact Locations from Aeromagnetic Data over Loum-Minta Area (Centre-East Cameroon)
}

\author{
Jean Aimé Mono ${ }^{1,2 *}$, Theophile Ndougsa-Mbarga ${ }^{1,3 *}$, Marcelin Bikoro Bi-Alou${ }^{4}$, Jean Daniel Ngoh ${ }^{1}$ \\ Olivier Ulrich Owono ${ }^{1}$
}

\author{
${ }^{1}$ Postgraduate School of Sciences, Technologies \& Geosciences, University of Yaoundé I, Yaoundé, Cameroon \\ ${ }^{2}$ Basical Sciences Teaching Department of Advanced Technical Teacher Training School, University of Douala, Douala, Cameroon \\ ${ }^{3}$ Department of Physics, Advanced Teacher's Training College, University of Yaoundé I, Yaoundé, Cameroon \\ ${ }^{4}$ Department of Earth Sciences, Faculty of Science, University of Maroua, Maroua, Cameroon \\ Email: ^monojeanaime@yahoo.fr, ${ }^{\star}$ theopndougsa@gmail.com
}

How to cite this paper: Mono, J.A., Ndougsa-Mbarga, T., Bi-Alou, M.B., Ngoh, J.D. and Owono, O.U. (2018) Inferring the Subsurface Basement Depth and the Contact Locations from Aeromagnetic Data over Loum-Minta Area (Centre-East Cameroon). International Journal of Geosciences, 9, 435-459.

https://doi.org/10.4236ijg.2018.97028

Received: March 19, 2018

Accepted: July 24, 2018

Published: July 27, 2018

Copyright (c) 2018 by authors and Scientific Research Publishing Inc. This work is licensed under the Creative Commons Attribution International License (CC BY 4.0).

http://creativecommons.org/licenses/by/4.0/

\section{(c) (i) Open Access}

\begin{abstract}
The present study aims to estimate the basement depth and contact locations, deduced from the available aeromagnetic data. The total intensity aeromagnetic (TMI) map was first corrected by the application of the reduction to equator technique. Different edge detection processes, for example, tilt angle derivative (TDR) and its total horizontal derivative (HD_TDR) as well as 3D-Euler deconvolution can determine the edges of these sources. These techniques were carried out on the aeromagnetic data of Minta region (the study area). A correlation was noticed between these techniques indicating that both of them can be attributed in delineating the general structural framework of the area. The aeromagnetic data analysis enables to highlight many deeply-seated structural features trending in the E-W, ENE-WSW and NE-SW directions in this region. The E-W trend is more strongly developed than the other identified trends. Moreover that, two depth methods were applied: analytic signal (AS) and source parameter imaging (SPI). They reflected similar results for estimating the basement depths. From both of them the depth ranges from 150 to $2800 \mathrm{~m}$. Five methods (TDR, HD_TDR, 3D-Euler deconvolution, AS and SPI) for locating magnetic sources indicated that the depth of the basement rocks ranged between 150 and $3000 \mathrm{~m}$ as the average range. Also, the comparative study among the $2 \mathrm{D}$ magnetic modeling was established by one profile constructing.
\end{abstract}

\section{Keywords}

Power Spectrum, Multiscale Analysis (THDR_TDR, AS), Euler 
Deconvolution, SPI, Basement

\section{Introduction}

The magnetic method is one of the most commonly used geophysical tools. This stems from the fact that magnetic observations are obtained relatively easily and cheaply and few corrections must be applied to the observations. The aim of a magnetic survey is to investigate subsurface geology based on anomalies in the Earth's magnetic field resulting from the magnetic properties of the underlying rocks. The magnetization of rocks and associated remanence is affected by deformation, tectonism, magmatism and metamorphism hence they reflet geological processes [1]. The purpose of the application of the aeromagnetic interpretation is to help in solving the problems of regional geological mapping and structure, delineation of buried contacts and basement depth. Different methods, based on the use of the magnetic field derivatives, have been developed to determine magnetic source parameters such as locations of boundaries and depths. Many researchers [2] [3] used source parameter imaging (SPI) to determine the depth to basement surface. The aeromagnetic method has been used in many geophysical studies in Cameroon [4]-[11] to map tectonic structures such as faults, lineaments, fractures and to highlight non-flush geological structures. Such structures may serve as potential hosts for a variety of minerals and may be used as guidance for exploration of the epigenetic, stress-related mineralization in the surrounding rocks [12]. The current study investigates the transition zone between the north margin of the Congo Craton (CC) and the North Equatorial Fold Belt (NEFB). Many authors [13] [14] invoke the thrusting of the NEFB over the CC. Besides, the study area has been affected by some shears that gave rise to many major faults including the Sanaga Fault (SF). This NE lineament is an active fault corresponding that may be to the north margin of the CC [15] [16]. The purpose of the present work is to produce a picture for the basement depth and contact locations, deduced from the available aeromagnetic data. In this paper, different techniques (TDR, HD_TDR, 3D-Euler deconvolution, AS and SPI) have been applied on the Minta area to locate the boundaries and the depths of the magnetic sources given the complexity of the geology of the study area in order to have better results. It is interested to correlate between these edge detection methods to measure the degree of similarity between their results. AS and SPI are used to calculate the depth to basement of the study area. Correlation between them also should be noticed.

\section{Geological and Tectonic Setting of the Study Area}

The area that is the subject of our study is east of Yaoundé (Central Cameroon). It covers the portions of the departments of Haute Sanaga (capital city Nanga Eboko) in the central region, Nyong and Mfoumou (capital Akonolinga) in the 
Central region, and Upper Nyong (capital city Abong-Mbang) in the Eastern Region. The area under study has a relatively monotonous relief, with an altitude which is between $600 \mathrm{~m}$ and $700 \mathrm{~m}$. Our survey area is crossed on the north by the Sanaga River flows in a sinisteral ductile fault oriented N70E and corresponds to a westward extension of the Bozoum fault-N'délé located in the Central African Republic [16]. The Mobile zone of Central Africa which limits the Congo Craton to the north and continues in northeastern Brazil by the Sergipano range [17] [18] (Figure 1(a)) is interpreted as a continent-to-continent collision chain involving the Congo craton and the northern Cratonic domain of Adamaoua-Yadé [19] or the active border of northern-central Cameroon [20]. In Cameroon, it is subdivided into supergroup of the north and supergroup of the south by the shear zone of the centre of Cameroon (CCSZ) [21] (Figure $1(\mathrm{~b}))$ :

1) The Northern Cameroon Supergroup (NCSG) consists of metase-dimentary rocks known as the Poli Group which is associated with subordinate $830 \mathrm{Ma}$-old volcanics of fault and alkaline affinities (Figure 1(b)). Widespread $630-660$ Ma-old calc-alkaline granitoids from Adamawa and West Cameroon Groups were transformed to gneisses. The inherited zircons in the granitoids provide ages up to $2 \mathrm{Ga}$ and may attest a Palaeoproterozoic crustal source in this region [19].

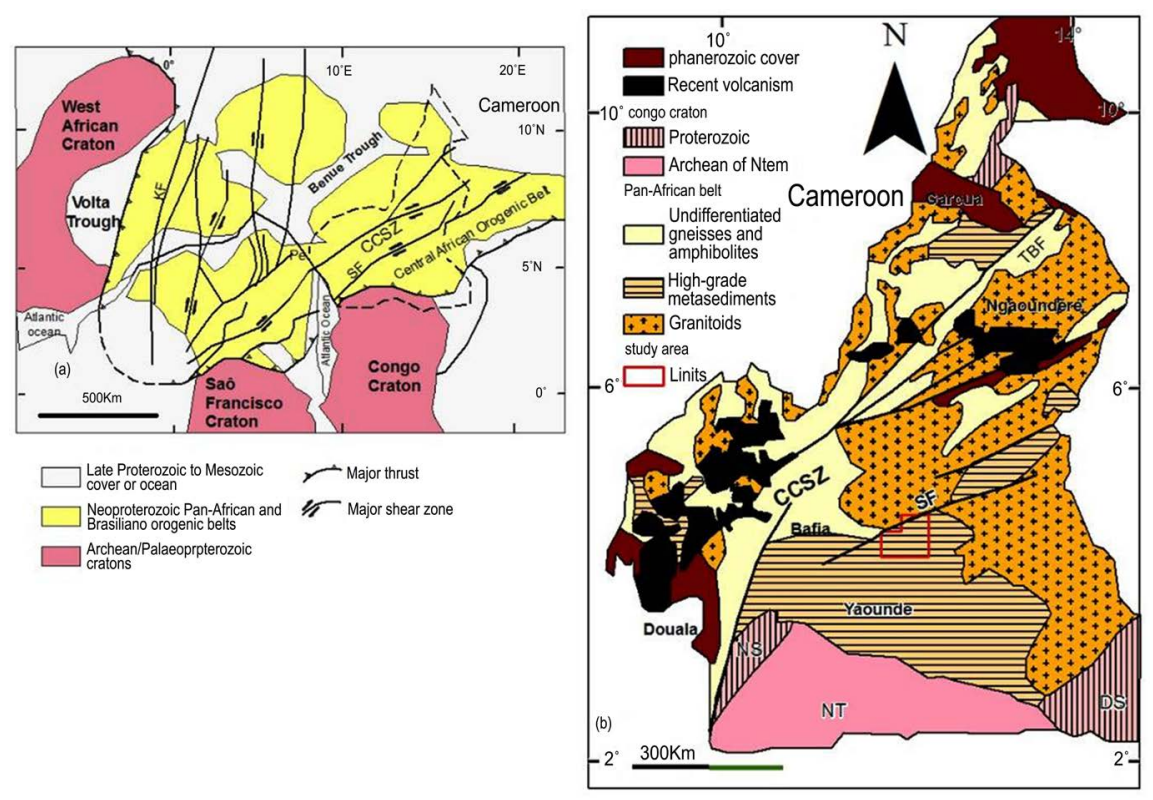

Figure 1. (a) Geological sketch map of west-central Africa and northern Brazil with cratonic masses and the Pan-African and Brasiliano provinces of the Pan-Gondwana belt in a Pangea reconstruction; modified from [22]. CCSZ: Central Cameroon Shear Zone; KF: Kandi Fault; Pe: Pernambuco Fault; SF: Sanaga Fault; TBF: Tibati-Banyo Fault. Dashed outline roughly marks the political boundary of Cameroon; (b) Geological map of Cameroon with the two main domains of the Pan-African orogenic belt, modified from [25]: (1) Northern domain; granitoid suites are not further distinguished; (2) Southern domain corresponding to the Yaounde series thrusted onto the Congo Craton. CCSZ: Central Cameroon Shear Zone; DS: Dja series; NS: Nyong series; NT: Ntem complex; SF Sanaga Fault; TBF: Tibati-Banyo Fault. Location of study is marked by a square. 
2) The Southern Cameroon Supergroup (SCSG) is subdivided in two domains by the Sanaga Fault (Figure 1(b)). These large NE-striking transcurrent faults are regarded as possible prolongations of the major shear zones of NE Brazil in a pre-drift Gondwana recon-struction [22] [23]. The northern domain consists of high-grade gneisses, intruded by widespread Neoproterozoic syntectonic plutonic rocks of high-K calc-alkaline affinities [24] [25] [26]. The southern domain comprises Neoproterozoic lithostructural units of metasedimentary rocks, such as the Yaounde, Lom, Dja and Yokadouma Groups [27]. Protoliths of these units were deposited in a passive margin environment at the northern edge of the Congo craton. An alkaline magmatism [28] [29] was also recognized in association with these Neoproterozoic units. The rocks of this southern domain were transported top-to-the SSW onto the Archean Congo craton [29] [30] [31]. The thrust zone continues towards the east, forming the Oubanguides Complex in the Republic of Central Africa [32] [33].

The study area situated at the east of Yaounde (Figure 1) belongs to the Southern Cameroon Supergroup (SCSG) and the Oubanguide Complex [33] [15]. It is at the limit of the granite formations that occupies the greater part of Adamaoua and the Yaounde group. The Yaoundé group is a huge allochtonous nappe thrusted southward onto the Congo craton. According to recent investigations, it underwent amphibolite- to granulite-facies medium- to high-P-T metamorphism with subsequent retrogression during the Pan-African (616 Ma) orogeny [28] [29]. A major part of the Yaounde Group is composed of metasedimentary rocks with predominant micaschists and paragneisses. The geological map of [34] (Figure 2) shows that the area is covered with granites and the ancient metamorphic series of Nanga-Eboko. The northern part of the newer, less metamorphosed series of Akonolinga is south of the study area. The granite
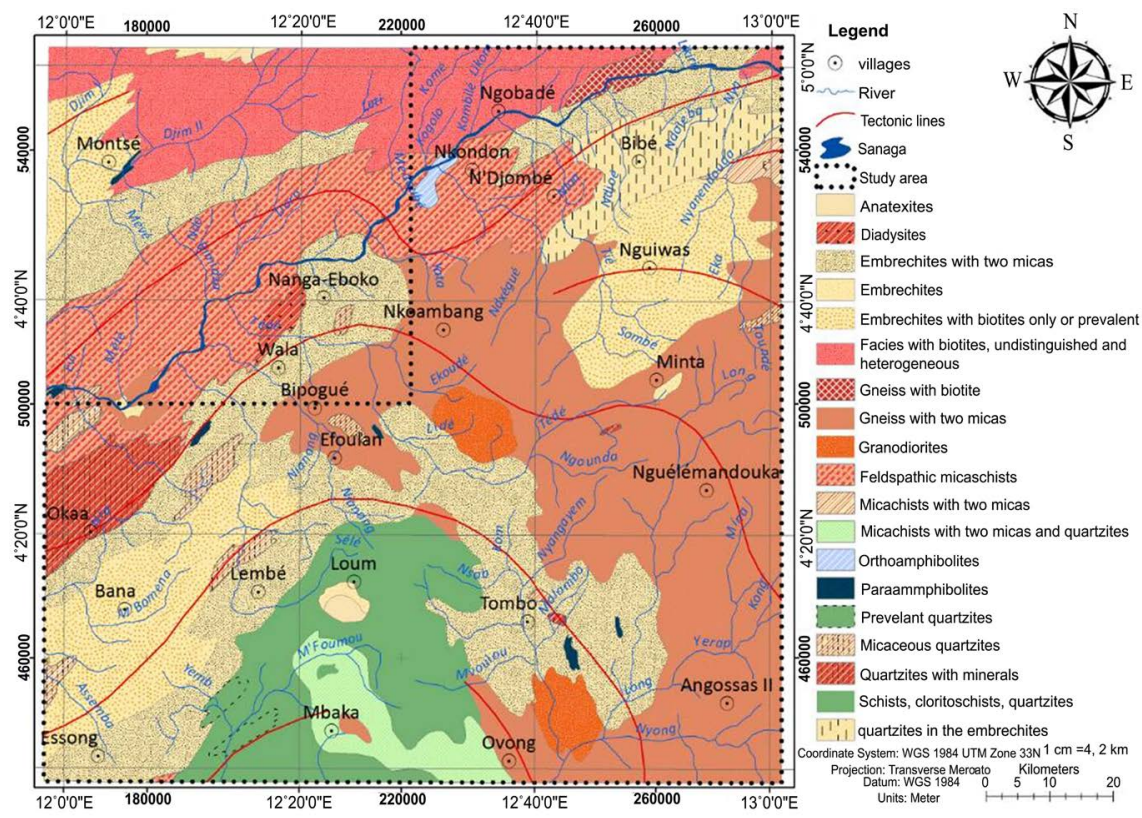

Figure 2. Geological map of the study area [34]. 
formations, ancient syntectonic granite, is represented in the north of the region, in Ngobadé. It is a heterogeneous granite, both in structure and texture, and in its mineralogical composition: the dominant type is a calc-alkaline granite. The granodiorite massifs in the south of Nkoambang and north-east of Ovong are well individualized in the middle of metamorphic rocks: the rock is granular and contains, among others, andesine, very ferriferous biotite and hornblende. The metamorphic series of Nanga-Eboko constitutes the substratum of the study area: the series is strongly folded and the dips are very variable, which does not allow to easily reconstruct the stratigraphy and the tectonics of these formations [35]. It is mainly composed of ectinites and migmatics. Among the ectinites, the two-micas gniess form a broad band, from Nkoambang to Angossa through Nguélémendouka: the most frequent facies is garnet and there are some quartzite zones in the gneisses. Biotite gneisses are not well represented: the north-east of Ngobade. The micaschists with two micas are noted in the west part of bibé; in the north-west, between N'Djombé and Nkondon. At the base of these mica-schists is a feldspar facies. Embrechite is the only migmatite represented in the study area. It is found in Minta to Bibé, in contact with the granites and in contact with two micas gneisses in Minta [4]. It also forms a broad band from Bana to Tombo. They are in contact with the northern part of the Akonolinga series and two massifs of granotoides. We distinguish facies with two micas (Tombo) or biotite alone or dominant. Quartzite facies is particularly visible in the Bibé sector. Amphibolites are present in the south of the region in biotite embrechites, but do not form large massifs. The northern part of the less metamorphosed series of the south of Akonolinga in the study area is mainly composed of chlorite-schist and quartzite.

The tectonic evolution of the area was affected by the Pan-African tectonothermal event which is characterized by a polyphase deformation with the stages $\mathrm{D}_{1}-\mathrm{D}_{4}$ as reported by [26] [27] [29] [31]. $\mathrm{D}_{1}$ predated emplacement of calc-alkaline dioritic bodies and caused the formation of nappes that resulted in high-pressure granulite metamorphism of soft sediments. A strong overprinting of these nappes during $\mathrm{D}_{2}$ symmetric extension, probably associated with large-scale foliation socking and (or) gneissic doming and intense magmatic underplating, gave rise to regional flat-lying fabrics. The latter were further buckled by $\mathrm{D}_{3}$ and $\mathrm{D}_{4}$ folding phases defining a vertical constriction occurring with a major east-west to NW-SE shortening direction. The corresponding $\mathrm{F}_{3}$ and $\mathrm{F}_{4}$ folds trend north-south to NE-SW and east-west to NW-SE, respectively, and represent the main regional strain patterns. Based on the east-west to NW-SE maximum shortening orientation indicated by $\mathrm{F}_{3}$ folds, it is proposed that the nappe-stacking phase $\mathrm{D}_{1}$ occurred in the same direction.

\section{Materials and Methods}

\subsection{Aeromagnetic Data}

The key component of this study involved image enhancement of existing aero- 
magnetic data sets acquired by the company SURVAIR (contractor) for the CIDA (client) in 1970. The survey was carried out in a nominal field clearance of $235 \mathrm{~m}$ which was monitored by a radar altimeter with an accuracy of $\pm 20 \mathrm{~m}$. The line spacing of the flight was $750 \mathrm{~m}$ but the real distance rarely went above $1 \mathrm{~km}$ and the flight direction was N-S. After correction of the measurements for the temporal variations of the magnetic field, the total magnetic intensity map of the study area is obtained with the inclination and declination angles of the ambient $-15.92^{\circ}$ and $-5.73^{\circ}$ respectively, in January 1970 according to IGRF.

\subsection{Total Magnetic Intensity Reduction to the Equator (RTE)}

In geomagnetic methods the shape of magnetic anomalies due to vertical bodies depends on the inclination and declination angles of the geomagnetic field. In the north and south magnetic poles the main field plunges vertically and magnetic abnormalities have a symmetric shape, with the maximum or minimum located directly over the causative magnetic body. At low magnetic latitude (between $15^{\circ} \mathrm{S}$ an $15^{\circ} \mathrm{N}$ ), it is not very easy to correlate the observed abnormal maxima and the positions of sources since magnetic signature of magnetized bodies at low latitudes always have two extreme values because of their bipolar nature. To remove this effect, as the name suggests, the reduction to the pole (RTP) transforms the data to the signal that would be measured at the magnetic poles [36]. This puts the limits of the magnetic abnormalities directly over their sources, like gravity abnormalities, thus making magnetic interpretation easier and more reliable. In low latitude, it not possible to apply RTP, the north-south direction is accentuated, and it is generally unstable and cannot be very useful. To facilitate the interpretation of the abnormalities at very low latitudes, we transform the analytic maps in the space domain: this is the case for the reduction-to-the-equator (RTE). After [37], the magnetic data can also be reduced to the equator (RTE) such that the magnetic bodies will appear horizontal at the equator. The TMI grid data were then transformed using the RTE filter, instead of the reduction to the pole filter, since the study area located within the low magnetic latitudes (i.e. areas with geomagnetic inclination less than $15^{\circ}$ ) in which a satisfactory reduction to the pole (RTP) of magnetic data is not possible. The TMI-RTE grid data of the area were processed er to transform and enhance magnetic anomalies associated with the edges of surface/near surface geological bodies, structures and depths. The methods used are the tilt angel derivative (TDR) and its total horizontal derivative (TH_DTD), analytic signal (AS) where the first vertical derivative (FDV) has been used. The MAGMAP two-dimensional Fast Fourier Transform (2-D FFT) filters package, EULER3D and SPI of GX's (Geosoft eXecutable) in the Oasis Montaj v8.4 software was employed in the study.

\subsection{The Tilt Angle Derivative (TDR) and Its Total Horizontal Derivative (THDR_TDR)}

TDR and THDR_TDR are used for mapping shallow basement structures and 
mineral exploration targets [38]. The tilt filter [39] [40] [41] [42] has also become a popular enhancement with an output given by TDR, used for enhancing features and causative body edge detection in potential field images. [39] suggested the tilt angle filter. It was developed later by others such as [42] and [43]. It showed a considerable interest because of its fundamental and practical simplicity [44]. This filter is defined as:

$$
\mathrm{TDR}=\tan ^{-1} \frac{\mathrm{VDR}}{\mathrm{THDR}} \quad T D R=\tan ^{-1} \frac{V D R}{T H D R}
$$

where VDR is the vertical derivative and THDR is the total horizontal derivative. i.e.:

$$
\operatorname{TDR}=\tan ^{-1}\left(\frac{\frac{\partial f}{\partial z}}{\sqrt{\left(\frac{\partial f}{\partial x}\right)^{2}+\left(\frac{\partial f}{\partial y}\right)^{2}}}\right)
$$

The Tilt derivative (TDR) is similar to the local phase but uses the absolute value of the horizontal derivative in the denominator. Due to the nature of the arctan trigonometric function, all amplitudes are restricted to values between $+\pi / 2$ and $\pi / 2\left(+90^{\circ}\right.$ and $\left.-90^{\circ}\right)$ regardless of the amplitudes of VDR or THDR [42]. The Tilt derivatives vary markedly with inclination but for inclinations of $0^{\circ}$ and $90^{\circ}$, its zero crossing is located close to the edges of the model structures. Positive values are located directly above the sources while negative values are located away from them. Furthermore, the horizontal distance from the $45^{\circ}$ to the $0^{\circ}$ position of the tilt angle is equal to the depth to the top of the contact [43] [45] or the half distances between $-45^{\circ}$ and $+45^{\circ}$ [42].

[41] introduced the total horizontal derivative of the tilt derivative (THDR_TDR) defined as the square root of the sum of the squares of the horizontal derivatives and the tilt derivative of the magnetic field. It is expressed as:

$$
\text { THDR_TDR }=\sqrt{\left(\frac{\partial \mathrm{TDR}}{\partial X}\right)^{2}+\left(\frac{\partial \mathrm{TDR}}{\partial Y}\right)^{2}}
$$

The total horizontal derivative of the tilt derivative (THDR_TDR) is independent of geomagnetic inclination like to the analytic signal (AS). The difference between these derivatives is that the former is sharper and generates better-defined maxima centered over the body edges. Another advantage of this independence, that it will generate useful magnetic responses for bodies having induced or remnant magnetization, or a mixture of both [46].

\subsection{Analytic Signal (AS) Method}

Some authors [47] [48] introduced the concept of the analytic signal for magnetic interpretation and showed that its amplitude yields a bell-shaped function over each corner of a 2D body with polygonal cross section. [49] used the total magnetic gradient, which they called the $3 \mathrm{D}$ analytic signal to approximately es- 
timate positions of magnetic contacts and obtain some depth estimates from gridded data. The analytic signal is a complex function formed through a combination of the horizontal and vertical derivatives of the magnetic anomaly. In $3 \mathrm{D}$, the analytic signal of the magnetic anomaly field is defined as:

$$
A(x, y, z)=\frac{\partial f}{\partial x} \vec{i}+\frac{\partial f}{\partial y} \vec{j}+\frac{\partial f}{\partial z} \vec{k}
$$

where $\vec{i} \vec{i}, \vec{j}$ and $\vec{k}$ are unit vectors in the $x, y$ xand $z$ directions, respectively, $\frac{\partial f}{\partial y}$ is the vertical derivative of the magnetic anomaly field intensity, $\frac{\partial f}{\partial x}$ and $\frac{\partial f}{\partial y}$ are the horizontal derivatives of the magnetic anomaly field intensity. The amplitude of the analytic signal in 3D is given by:

$$
|\mathrm{AS}|=\sqrt{\left(\frac{\partial f}{\partial x}\right)^{2}+\left(\frac{\partial f}{\partial y}\right)^{2}+\left(\frac{\partial f}{\partial z}\right)^{2}}
$$

AS simplifies the magnetic signal of anomalies by centering anomalies over the magnetic body as well as, having peaks over the edges of wide bodies. Thus, a simple relationship between the geometry of the magnetic bodies and the transformed data are observed. The magnetic sources depths using the magnetic method are estimated from the ratio of the total magnetic AS to the vertical derivative analytic signal (AS1) of the total magnetic field.

$$
\mathrm{AS} 1=\sqrt{\left(\frac{\partial f v}{\partial x}\right)^{2}+\left(\frac{\partial f v}{\partial y}\right)^{2}+\left(\frac{\partial f v}{\partial z}\right)^{2}}
$$

On the maximum amplitude:

$$
D=\frac{\mathrm{AS}}{\mathrm{AS} 1} \times N
$$

where $f v$ is the first vertical derivative of the total magnetic field, and $\mathrm{D}$ is the depth to the magnetic body, $N$ is known as a structural index and is related to the geometry of the magnetic source. For example, $N=4$ for sphere, $N=3$ for pipe, $N=2$ for thin dike and $N=1$ for magnetic contact [50].

\subsection{D-Euler Deconvolution}

Euler deconvolution's technique is an equivalent method based on the Euler's homogeneity equation as developed by [50] following [51]'s suggestion and operating on gridded magnetic data. [50], and have explained the Euler deconvolution technique, more details in methodology and wider application regarding the Euler's source depth solutions. These Euler depth solutions not only estimate the depth, but also delineate the horizontal boundaries [52]. In a general case, scattered data points cannot provide superior solutions [53] [54]. Various researchers have used 3D Euler deconvolution technique for source depth estimations [55]-[61]. The method is based on the concept that anomalous magnetic fields of localized structures are homogeneous function of the source coordinate and, 
therefore, satisfies Euler's homogeneity equation. Usually the structural index (SI) is fixed and the locations and depths $\left(x_{0}, y_{0}, z_{0}\right)$ of any sources are found using the following equation:

$$
\frac{\partial f}{\partial x}\left(x-x_{0}\right)+\frac{\partial f}{\partial y}\left(y-y_{0}\right)+\frac{\partial f}{\partial z}\left(z-z_{0}\right)=\operatorname{SI}(B-f)
$$

where $f$ is the observed field at location $(x, y$, and $z)$ and $f$ is the base level of the field [regional value at the point $(x, y, z)]$ and SI is the structural index or degree of homogeneity. Therefore, we have assigned a value of 1.0 as a structural index to locate the possible magnetic contacts because it is particularly good at delineating the sub-surface contacts. We used an overlapping moving window of 10 $\mathrm{km}$ by $10 \mathrm{~km}$, a tolerance of $15 \%$ and a proportioned symbol base of 235 .

\subsection{Source Parameter Imaging (SPI) Technique (Local Wavenumber Technique)}

This method developed by [62] also known as local wavenumber technique, all the parameters that make up the source which include depth, dip and susceptibility contrast are computed from the complex analytical signal. [63] related the source depth to the local wavenumber $(k)$ of the magnetic field which can be derived from the calculated total horizontal and vertical gradients of the RTE grid. In this method, the function used is the local wavenumber [61] given by:

$$
k(x, y)=\frac{\frac{\partial^{2} f}{\partial x \partial y} \frac{\partial f}{\partial x}+\frac{\partial^{2} f}{\partial y \partial z} \frac{\partial f}{\partial y}+\frac{\partial^{2} f}{\partial^{2} z} \frac{\partial f}{\partial z}}{\left(\frac{\partial f}{\partial x}\right)^{2}+\left(\frac{\partial f}{\partial y}\right)^{2}+\left(\frac{\partial f}{\partial z}\right)^{2}}
$$

For the dipping contact, the maxima of $\mathrm{k}$ are located direct over the isolated contact edges and are independent of the magnetic inclination, declination, dip, strike and any remnant magnetization. The depth is estimated at the source edge from the reciprocity of the local wavenumber, as follows:

$$
\operatorname{Depth}_{(x=0)}=\frac{1}{k_{\max }}
$$

where $k_{\max }$ is the peak value of the local of number $k$ over the step source.

\section{Results and Discussion}

\subsection{Total Magnetic Intensity Map}

The present total intensity aeromagnetic (Figure 3 ) exhibits some different types of positive (mengata and red colors) and negative (light and dark blue colors) anomalies. The first are the strong positive anomalies and the second are the negative anomalies. The map reveals two prominent negative features in elliptical and broad shapes distributed in the north-east (at Nguiwas) and southwestern part (at Bana) and shows the maximum negative of $-201.86 \mathrm{nT}$. These anomalies are trending NE-SW. We also observe some circular magnetics trends, with magnitudes above $111.60 \mathrm{nT}$. They are found in the south of N'Djombe along 


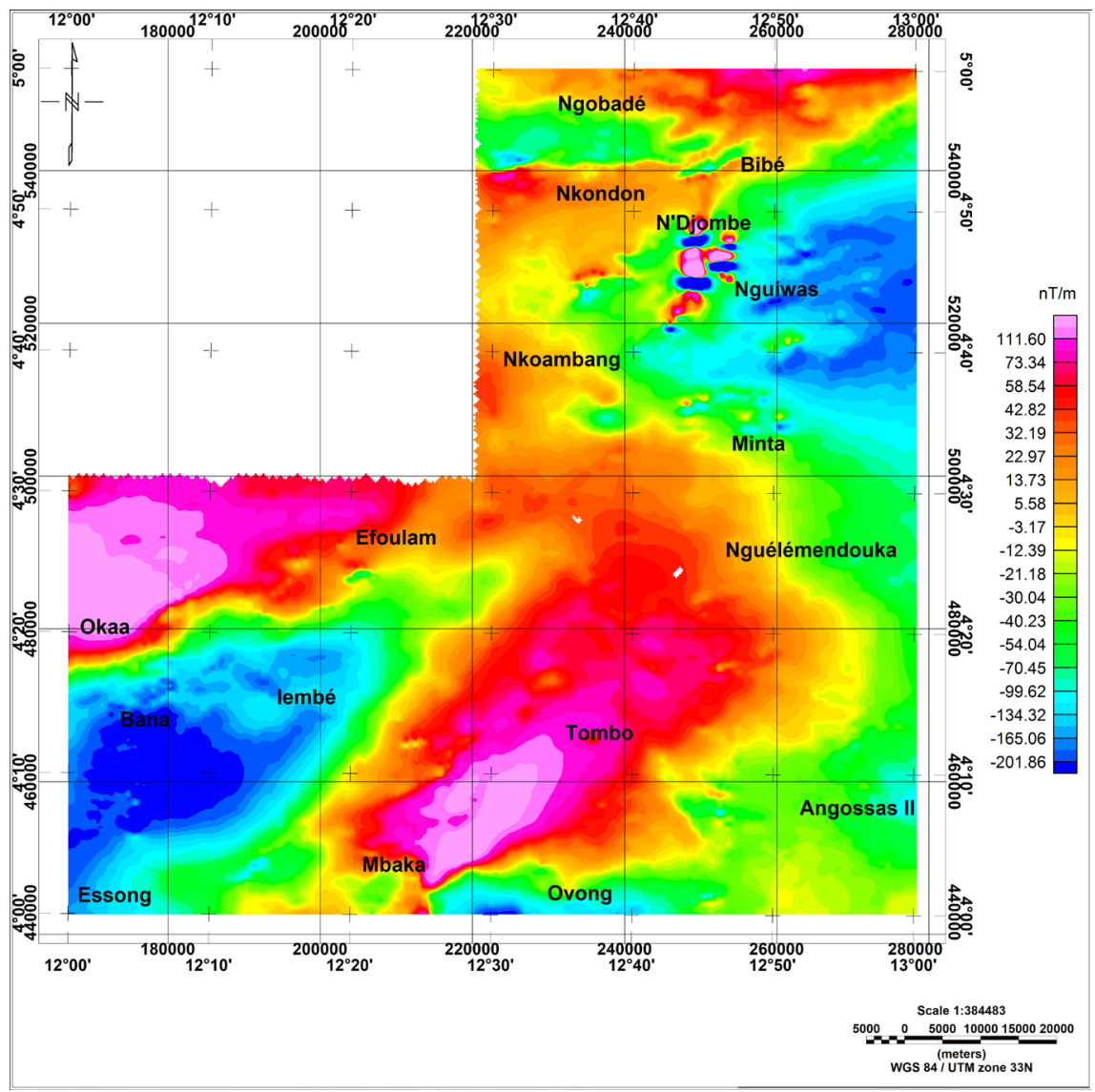

Figure 3. Total magnetic intensity (TMI) anomaly map of the study area.

$530,000 \mathrm{~m}$ and 520,000 m latitudes. These circular trends with large magnitudes suggest the presence of highly magnetized cylindrical intrusive bodies within the basement. The map illustrates a large positive magnetic zone located to central part. Another positive magnetic anomaly is located at the western part of the map (at Bana), which attains amplitude of $+120 \mathrm{nT}$ and trends along E-W attitude. The correlation of TMI anomalies map and geological contact is weak. It is noted that the positive anomalies are limited to the west by a weak gradient (quasi-horizontal gradient) showing the intensity of the geological formations overlaping. The Bana-Okaa region is formed by a bipolar anomaly: a negative pole in Bana with a long wavelength of $44.4 \mathrm{~km}$ and negative amplitude of $-201.86 \mathrm{nT}$, and a positive pole in Akaa with a high amplitude of $+120 \mathrm{nT}$ and wavelength of $54.6 \mathrm{~km}$. In the Minta zone, there is also a horizontal gradient of oblong and NW-SE direction that seems to correspond to the Nkoambang-Nguelemendouka tectonic line highlighted on the geological map.

\subsection{Total Magnetic Intensity Reduction to the Equator (TMI-RTE) Map}

The total Intensity Magnetic Map (Figure 3) is reduced to the equator (Figure 4) using Oasis Montaj software v8.4. On this map (i.e. TMI-RTE) the examination of the amplitudes of anomalies also reveals that the maximum and 


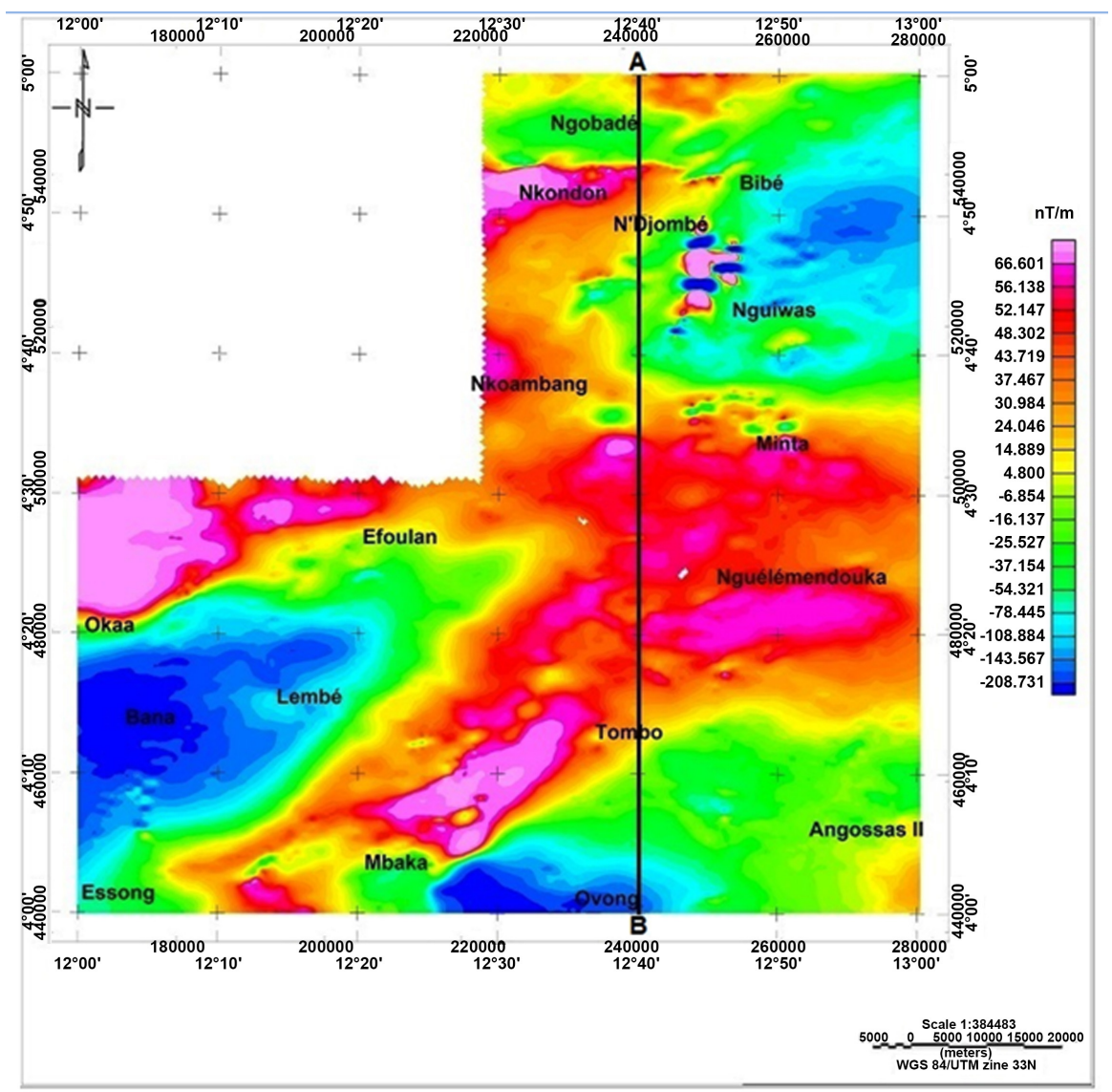

Figure 4. Reduced to equator of total magnetic intensity (TMI-RTE) anomaly map of the study area.

minimum values in the TMI-RTE map have reduced to $+66.60 \mathrm{nT}$ and increased to $-208.73 \mathrm{nT}$. From Ovong to Bibé, positive TMI anomalies have shifted slightly vertically to the north. On the other hand, from the southwest to the west of the study area, the anomalies preserve generally their forms compared to TMI. The circular magnetics trends in the south of N'Djombe persist. On the TMI-RTE map, the study area can be subdivided into fourth magnetic zones, each having a unique magnetic anomaly pattern (Figure 4); this magnetic zoning is mainly dependent upon the magnetic properties (e.g. magnetic susceptibilities) of the underlying rock types.

The first zone occupies the north-eastern (at Nguiwass), south-western (at Bana) and south (Ovong) parts of the area and is underlain by the Precambrian crystalline basement rocks (migmatites, especially embrechites, quartzite in embrechite). It is characterised by very low, Broad and elongate wavelength (low wavenumber) anomalies with magnetic intensity amplitude varying from -208.73 to $-78.44 \mathrm{nT}$ (light and dark blue colors). The second zone occupies the west (north of Akaa), south-central (Mbaka-Tombo), north-west (Nkondo) parts of the area. It is underlain by the ectinites of the old metamorphic series of Nanga-Eboko (especially quartzites with minerals in the west part, feldspathics micaschists in the north part and schisto-quartz group of Akonolinga in the 
south-central). It exhibits high (positive) anomalies: amplitudes of the magnetic intensity in this zone range from +66.60 to $+90 \mathrm{nT}$ (magenta and red colors). The third zone occurs within the part of the area underlain by gneiss with two micas at Angossa II. It displays relatively low (negative) to moderate (positive) magnetic anomalies. Amplitudes of the magnetic intensity in this zone range from -54.32 to $+4.80 \mathrm{nT}$ (green ligth and yellow ligth) (Figure 4). The fourth zone occupies the central-part (Tombo-Nguelemendouka-Minta) and north-west (Nkoambang-south of Nkondon) of study area. It exhibits intermediate (positive), long-wavelength magnetic anomalies trending mainly in the E-W direction. It is underlain by gneiss with two micas.

\subsection{The Tilt Angle Derivative (TDR) Map and Its Total Horizontal Derivative (THDR_TDR)}

The TDR_TMI-RTE analysis of [39] (Figure 4) exhibits the geologic features like faults, which are depicted as magnetic lineaments. This method facilitates the horizontal location with extended edges. It is suggested that the zero-contour line (the bold black line) in the TDR_TMI-RTE map is the location of abrupt changes in magnetic susceptibilities between positive and negative anomalies which are particularly at the sharp gradient. Therefore, the zero-contour line represents the contact boundary of magnetic sources. Zero contours can be identified as light-yellow color which is separating the green color (negative values) and red colors (positive values) as seen in the color scale bar (Figure 5). Also, positive values are located directly above these magnetic sources while negative ones are located away from them. Generally, the TDR of TMI-RTE magnetic data shows an NE lineament trend in the south-west (Essong-Mbaka-Tombo). Also, the map shows E-W trends in the centre and ENE-WSW trends in the east. According to the TDR map, the study area thus presents the cumulative characteristic features of a brittle tectonic and tangential tectonic, which are materialized by the different trends obtained, probably reflecting the existence of an ancient tectonic heritage taken up in folds and sheared during late tectonic episodes in the Central Africa mobile zone. The tilt map allows for a combined analysis of 2D structure boundaries and depth. [43] showed that for the tilt angle operator, applied to pole-reduced data, for vertical contact, the null value of the angle corresponds to the limit of the structure and the distance between the contours $\pm \pi / 4$ radian $\left( \pm 45^{\circ}\right)$ and the zero-valued contour is equal to the depth of the structure. By applying the method of [43], the depth varies from a few hundred to north of the study area to over 3000 meters in the confined area between Nkoambang, Tombo and Lembé in the south-central part of the region.

A total horizontal derivative filter was applied to the tilt derivative of the TMI-RTE grid data to generate the THD_TDR anomaly map (Figure 6). Figure 6 shows the THDR of the TDR. The THDR_TDR preserves the amplitude enhancement by its ability to define edges of well-defined maxima. So, the amplitude of the THDR_TDR is related to the reciprocity of the depth to the top of the 


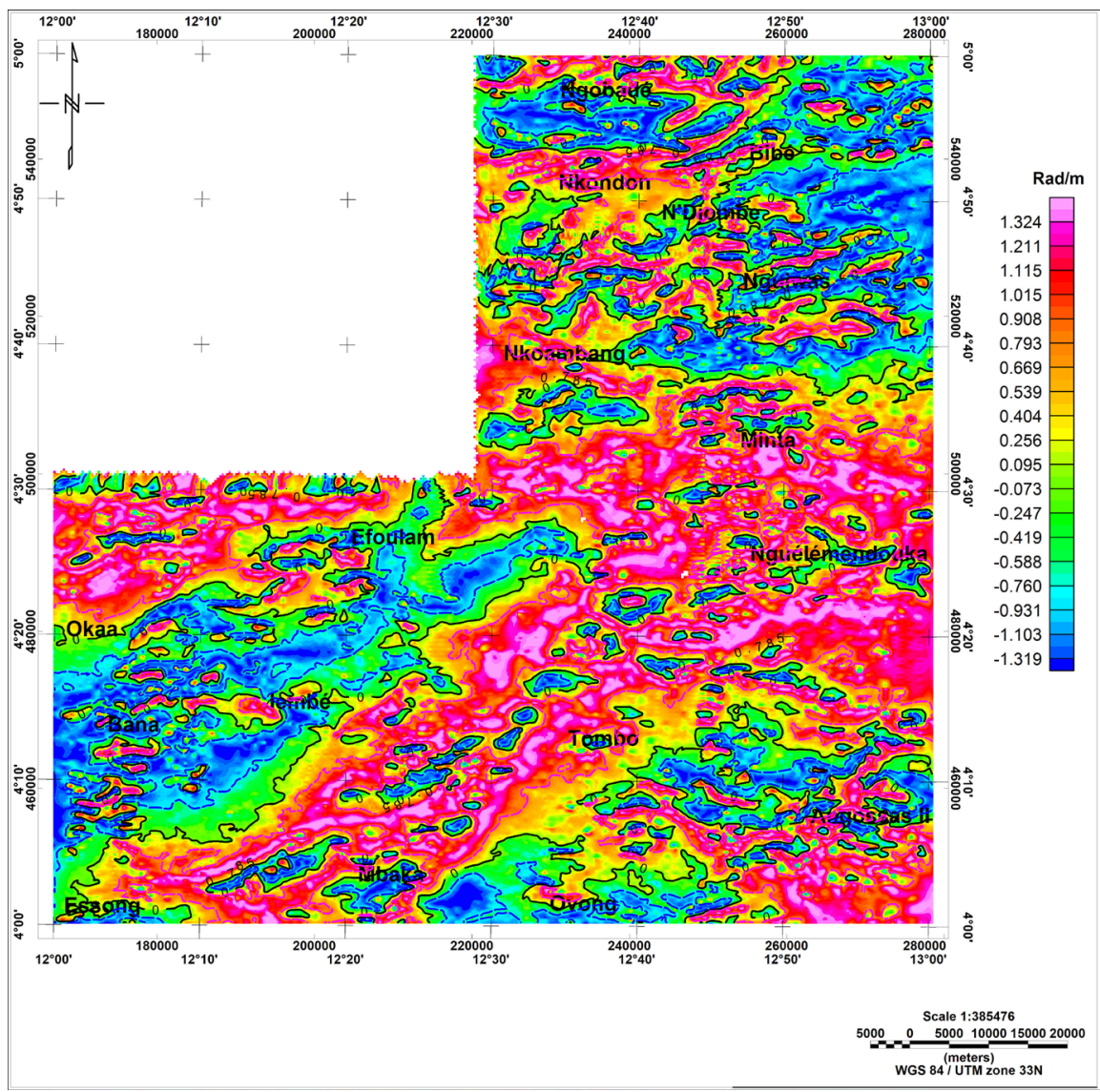

Figure 5. TDR_TMI-RTE map of area study.

source [64]. The tilt angle overcomes the problem of the shallow and deep sources by dealing with the ratio of the vertical derivative to the horizontal derivative; the tilt derivative will be relatively insensitive to the depth of the source and should resolve shallow and deep sources equally. However, from Figure 6 and its colored bar scale, the depth to the top of the sources ranges from 380 to about $2800 \mathrm{~m}$ all over the area except for dark blue area at the confined area in the south of Nguélémendouka, in the eastern part of the study area where its depth exceeds this value.

\subsection{Analytic Signal (AS) Map}

The amplitude of the analytic signal depends very little on the direction of magnetization [49] and is almost independent when the sources are vertical [65]. One of the advantages of the analytical signal is that it makes it possible to locate the position of the sources in the horizontal and vertical plane. Basement depth calculations were performed in the study area using AS, which was applied to the TMI-RTE data grid. The AS map of (Figure 7(a)) makes it possible to limit the contacts of the geological bodies of strong magnetization on this map. The limits of the intrusive bodies and faults are well highlighted. There is a linear structure at Nkondon while the intrusive bodies are grouped between N'Djombé and 


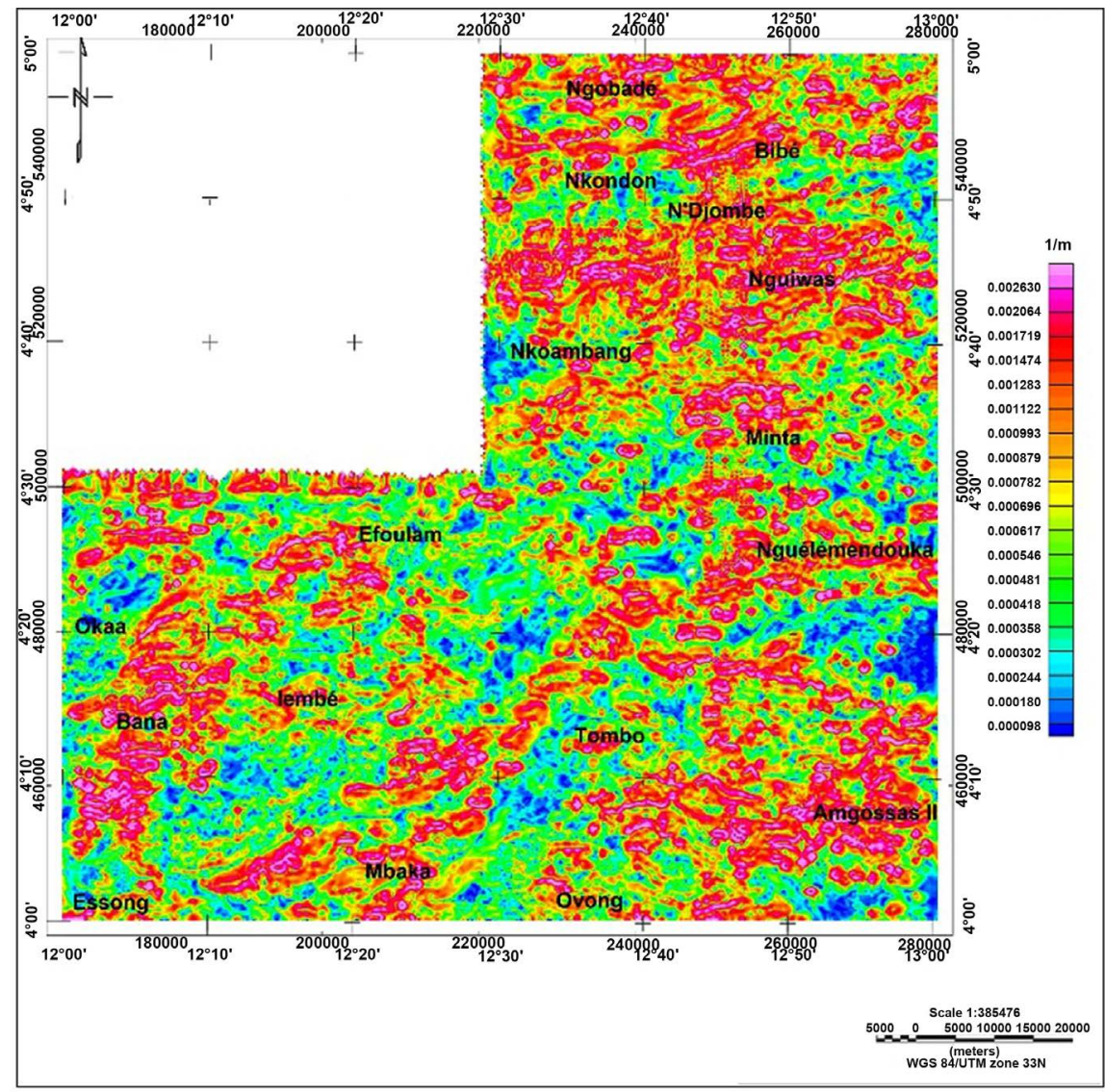

Figure 6. THDR_TDR map of area study.

Minta north of the study area, they are found in the south of the area in Bana and Mbaka. The map of the first vertical derivative for the TMI-RTE (Figure 7(b)) shows successively positive and negative anomalies that were almost invisible on the TMI and TMI-RTE, the positions and trends of these anomalies are similar to those of the TDR map (Figure 5). The analytical signal map of the first vertical derivative (Figure $7(c)$ ) is similar to the TMI-RTE AS map. The pseudo-circular shape anomalies have maximum amplitudes. According to equation (8) the AS data grid of the TMI-RTE board (Figure 7(a)) is divided by the data grid of the AS1 board (Figure 7(c)) to estimate the depth of the magnetic contacts of the base of the board the study area (Figure 7(d)). The map in Figure 7(d) highlights the spatial location of various magnetic sources at different depths. In general, the depth varies from $153.45 \mathrm{~m}$ to about $2685.24 \mathrm{~m}$ below sea level. It is noted that the areas in which the sources of anomalies are the deepest (at more than $2685.24 \mathrm{~m}$ ) are in Okaa, Efoulan, Lembé and Tombo, in the embroites according to the geological map.

\subsection{D-Euler Deconvolution (ED) Map}

Euler's deconvolution is one of the most reliable methods for obtaining depths under cover. In this investigation, ED solutions were calculated for IS $=1$ for 


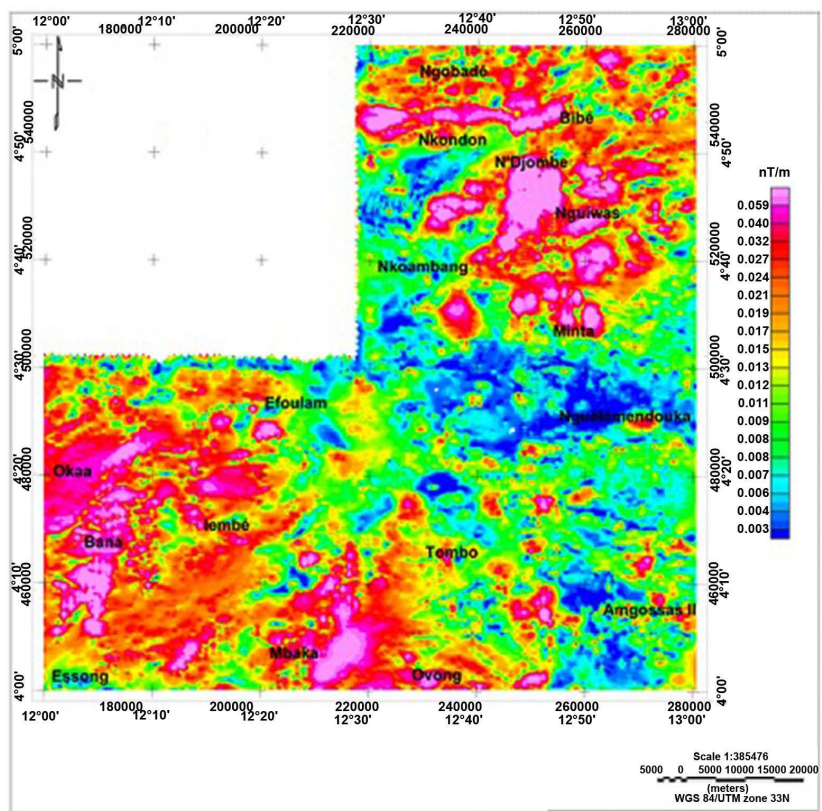

(a)

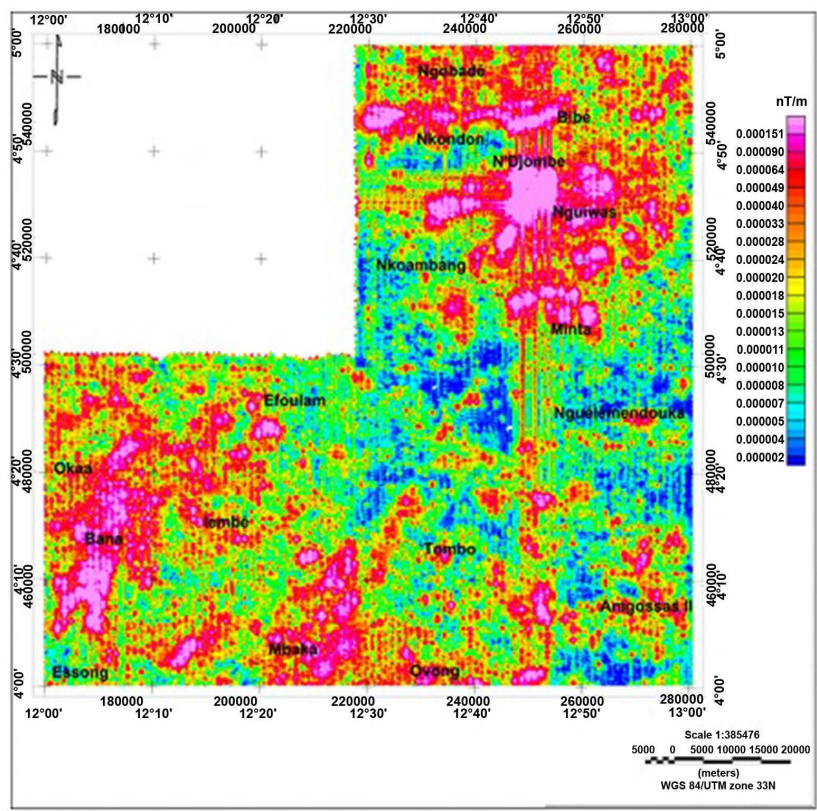

(c)

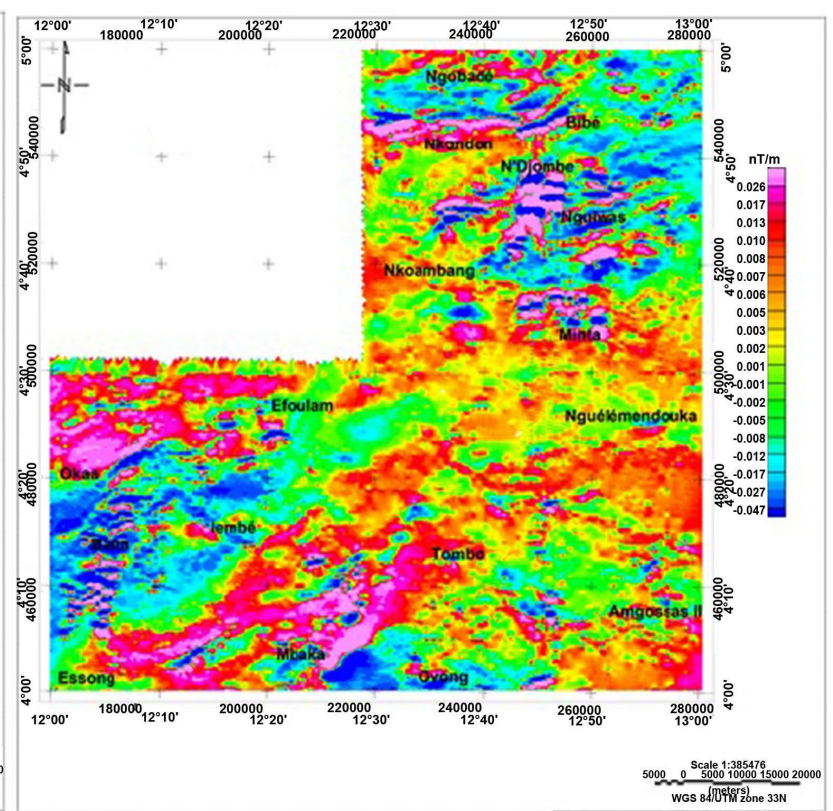

(b)

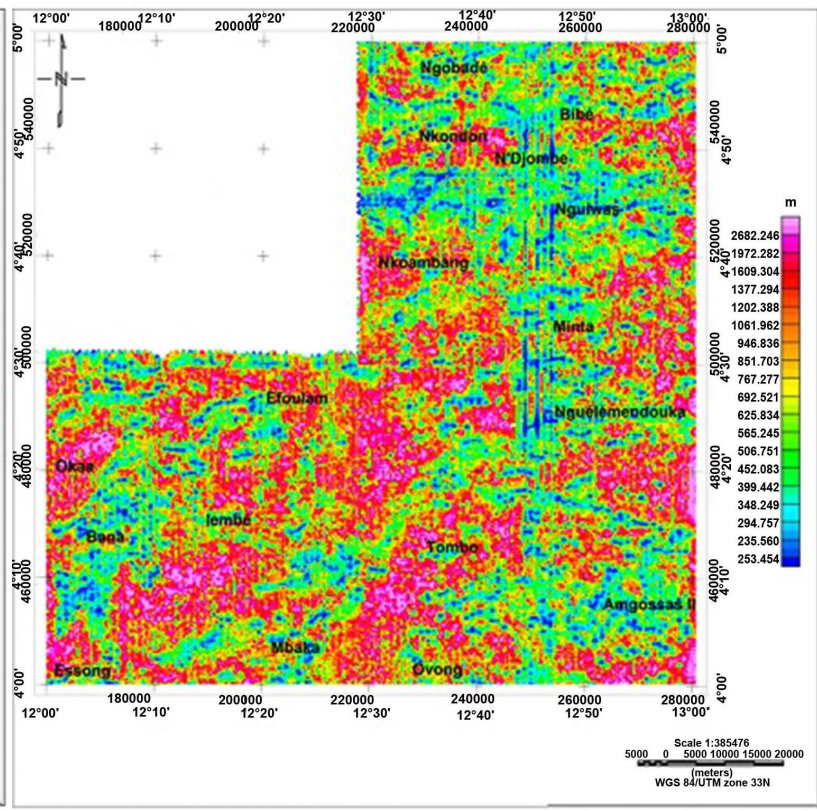

(d)

Figure 7. (a) Analytic signal, (b) First vertical derivative and (c) Analytic signal of first vertical derivative maps used to calculate (d) Basement depth map using analytic signal method.

thin-layer boundary (sill, oblique intrusive vein, banded iron formation, etc.) or faults [50]. The size of the window used is $10 \mathrm{~km} \times 10 \mathrm{~km}$ with a maximum depth tolerance of $15 \%$. A good grouping of solutions indicates that the location of the source is well resolved, and a dispersion indicates that the solutions must probably be ignored [50]. The Euler depth solution map is illustrated in Figure 8. The analysis of this map shows the linear clustering circles are suggested to be the result of faults and or contacts with depth values ranging between $245.24 \mathrm{~m}$ 


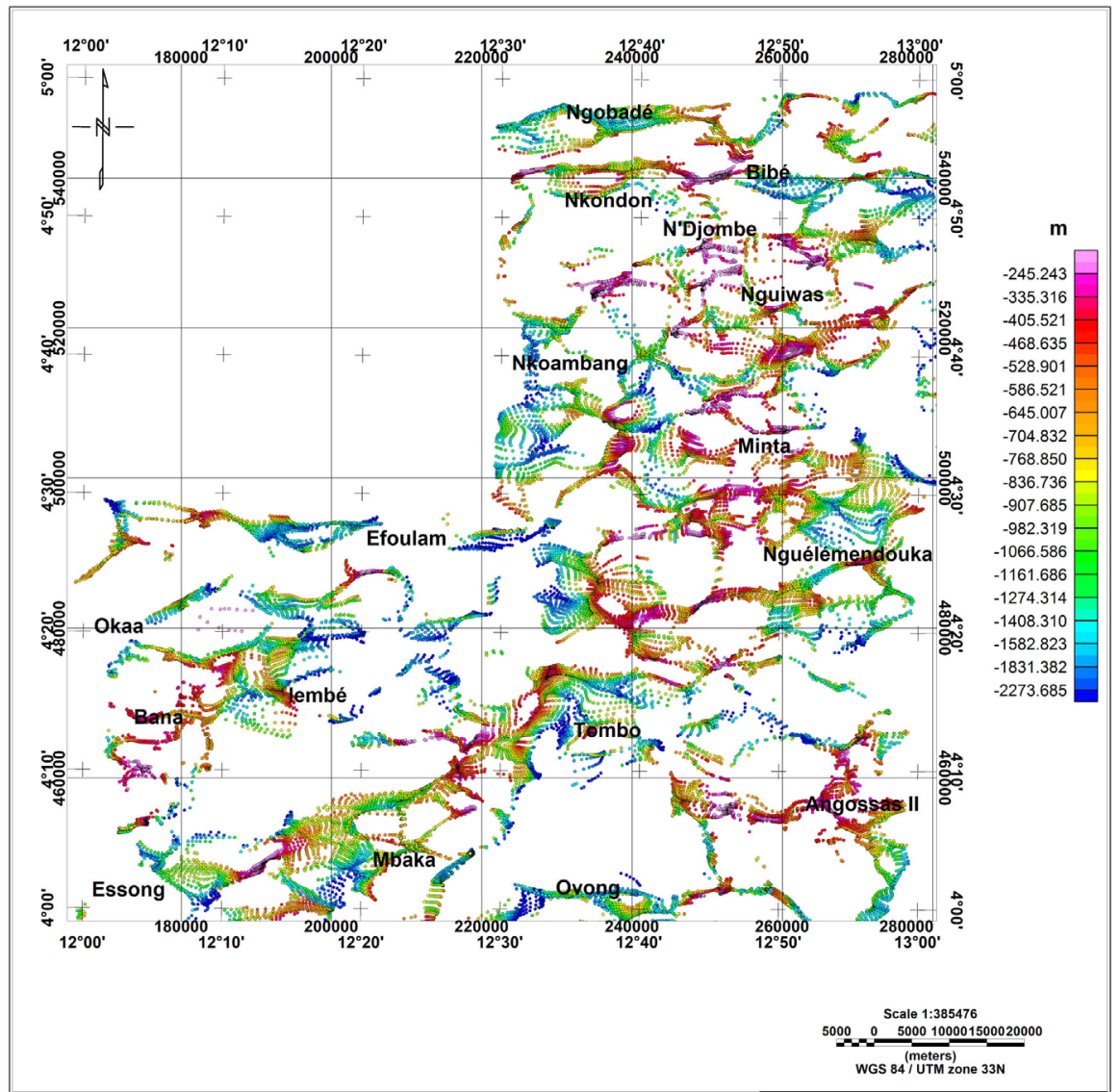

Figure 8. Euler's solution of TMI residual $\mathrm{N}=1, \mathrm{~T}=15 \%, \mathrm{~W}=10 \mathrm{~km} \times 10 \mathrm{~km}$.

and $2273.68 \mathrm{~m}$. The non-uniformity of the depths of said contacts in the area suggests that all the outlines of the box do not have the same origin. These solutions are trending in E-W, ENE-WSW and NE-SW directions.

On Euler's solutions map, the limits of the faults intrusive bodies are perfectly distinguished. To the north, at Ngobadé in the granites; in the center, between Nkoambang and Nguélémendouka; in the south, at Angossas II, the shape of the Euler solution groupings would characterize the limits of the intrusive bodies in the basement, whereas the straight and continuous alignment of the Bibé, Minta, Efoulan and Mbaka solutions would, on the other hand, characterize the normal faults hidden in the covers.

\subsection{Interpretative Structural Map}

An interpretative structural map has been drawn from maps of Figure 5, Figure 6 and Figure 8 to highlight the different lineaments (Figure 9). The interpretative structural map simply reveals the structural complexity in the basement, this map is characterized by trends of lineaments.

The analysis of the interpretative structural map of study area shows four predominant structural trends having variable intensities and lengths. These are the E-W, ENE-WSW and NE-SW trends, representing the most predominant 


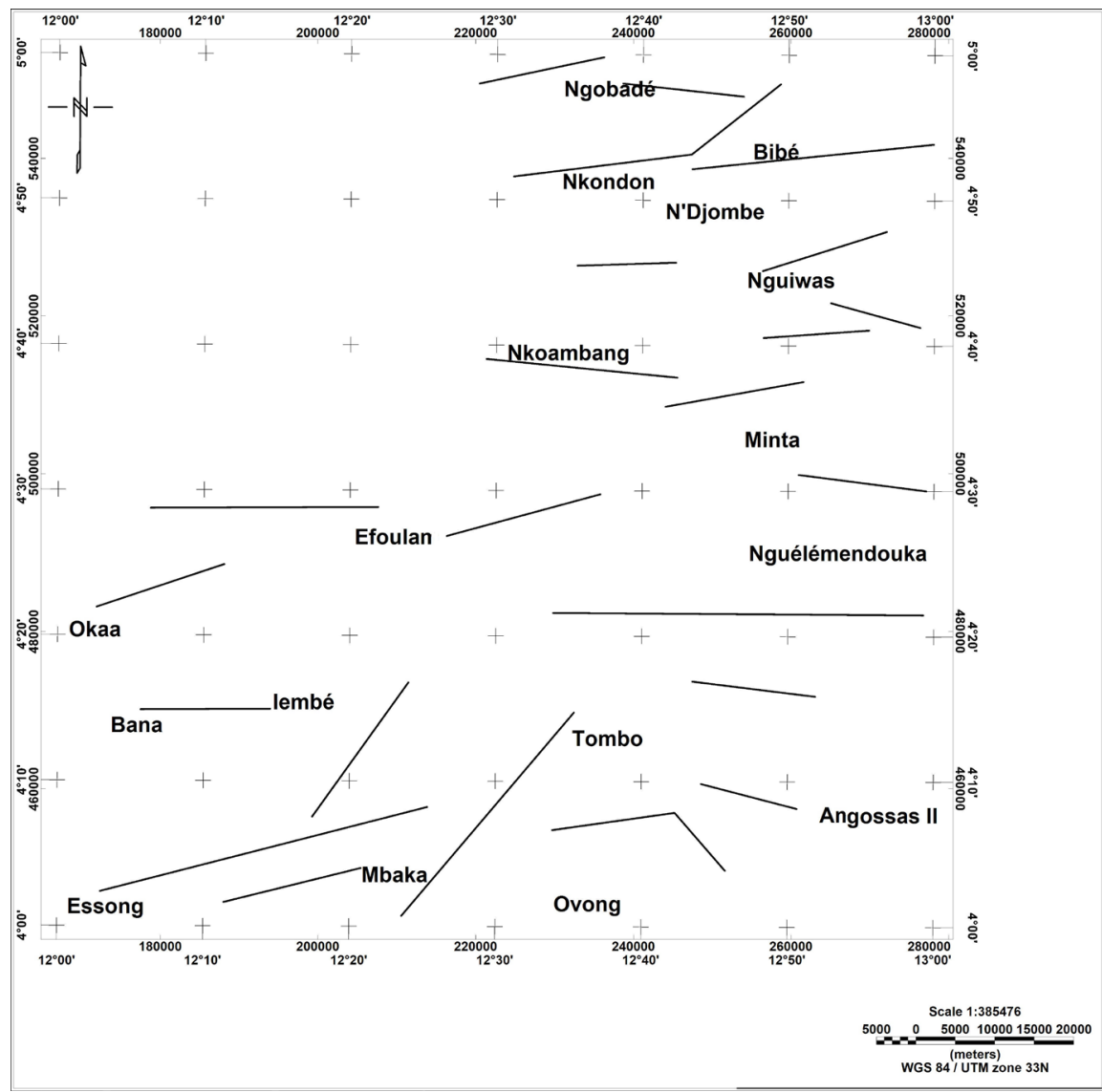

Figure 9. Interpretative structural map of study area.

tectonic trends affecting the investigated area as deduced from the magnetic point of view. The relationships among these trends suggest that, the area was subjected to more than a single tectonic event. Vertical accidents characterized by nearly rectilinear solutions have NE-SW directions at Okaa, E-W at Nkondon, Ovong. The deepest accidents are of E-W main directions with depths of over $2300 \mathrm{~m}$ and are in Efoulan, Lembé and Tombo. The folding system-oriented E-W to NE-SW, are in accordance with the directions highlighted in geological investigations focused the Awaé-Ayos strike-slip shear zones (southern Cameroon): Geometry, kinematics and significance in the late Pan-African tectonics by [66] in adjacent areas situated below the present study area. The ENE-WSW contacts after [67], is associated to the second deformation $\mathrm{D}_{2}$, characterized by folds $\left(\mathrm{S}_{2}\right)$, foliation $\left(\mathrm{F}_{2}\right)$. At the regional scale, the near surface NE-SW contacts who represent the regional deformation events $\mathrm{D}_{2}$ (compression) and D3 (wrenching) may correlate with the development of the Centre Cameroon Shear Zone witness by the Foumban Shear Zone.

The tectonic features put in evidence have linkages with faults and folds lines-oriented E-W, ENE-WSW and NE-SW, as identified by geophysical surveys carried out in gravity [68] [69] [70] [71], audiomagnetotelluric [6] and aeromagnetic [11] in areas situated around the current study area. 


\subsection{Source Parameter Imaging (SPI) Map}

The Source Parameter Imaging (SPI) module of the Oasis Montaj software was applied to the TMI data of the study area. The SPI (Source Parameter Image) method is a technique for calculating source depths from magnetic data. It is a tool based on the extension of the complex analytic signal to estimate magnetic depths [72]. The derived map (SPI) is illustrated in Figure 10 and highlights the spatial location of various magnetic sources at different depths. This map shows that generally, the north (from Nkoambang to Ngodabe) and south (Angossas II) parts of the study area are shallow. These areas are illustrated in blue, green and yellow colors represent depths ranging from 200 to $766.55 \mathrm{~m}$. They can be characterized by a low magnetic susceptibility. The central part (from Tombo to Nkoambang) is a deep zone and is characterized by orange, red and magenta colors with depths ranging from 988.19 to $2800 \mathrm{~m}$, which may be a high magnetic susceptibility.

The SPI depth map (Figure 10) shows a good similarity with the depth map constructed using the AS technique. However, the depth varies from about 200 $\mathrm{m}$ to about $2800 \mathrm{~m}$.

\section{2D Forward Modelling}

Theory and application modeling the source body of this study was performed

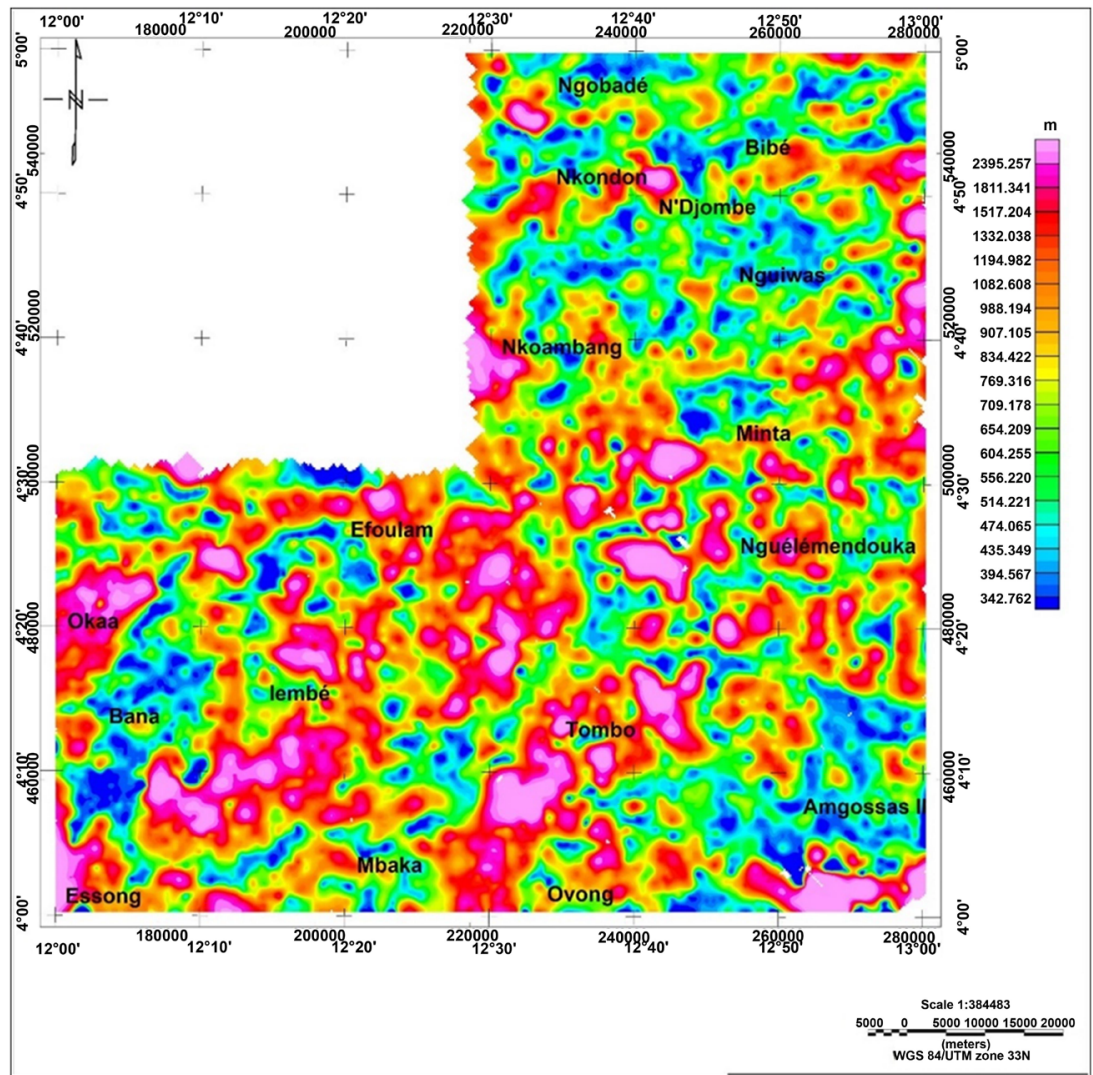

Figure 10. Map of the calculated depths with Source Parameter Image method (SPI) of the study area. 
by the Oasis Montaj's GM-SYS module 8.3 that permits forward modeling of magnetic data to obtain the optimal fit of the generated source model to the observed data. GM-SYS is based on the algorithms described by [73] and [74].

Using the available geologic information and the results of qualitative and quantitative interpretation of magnetic maps; basement structural cross-section is constructed along this profile to initiate modeling. The profile $\mathrm{AB}$ were chosen and drawn on the TMI-RTE map (Figure 4). This profile was drawn with a North-South orientation and traversing through the suspected area on the map. Profile $A B$ covers about a length of $111.05 \mathrm{~km}$. It has its origin at latitude $4^{\circ} 00^{\prime} \mathrm{N}$ and lies parallel on longitude $12^{\circ} 40^{\prime} \mathrm{E}$ up to latitude $5^{\circ} 00^{\prime} \mathrm{N}$. The profile runs through Ovong, Tombo and N'Djombé and crosses successively three lithologic unit of susceptibility $0.011 \mathrm{SI}, 0.036 \mathrm{SI}$ and 0.045 SI respectively (Figure 11). Close examination of this profile shows an excellent fit between the observed and calculated anomalies with error reaches 1.722 (Figure 11). Where the negative magnetic anomalies are related probably to the uplifts, whereas the positive ones are recognized with graben structures of the second lithologic unit. In the model, it is considered that the basement is granitic with a magnetic susceptibility of $0.045 \mathrm{SI}$ and the depths are ranging between $550 \mathrm{~m}$ and $4100 \mathrm{~m}$.

\section{Conclusion}

This study is based on the analysis and interpretation of aeromagnetic data to define the subsurface basement depth and contacts location's inference of the study area. First, the Total Magnetic Intensity Map reduced to the equator (TMI_RTE) is used to locate the magnetic anomalies directly above their causative sources. This map reveals various causative sources, as well as varying
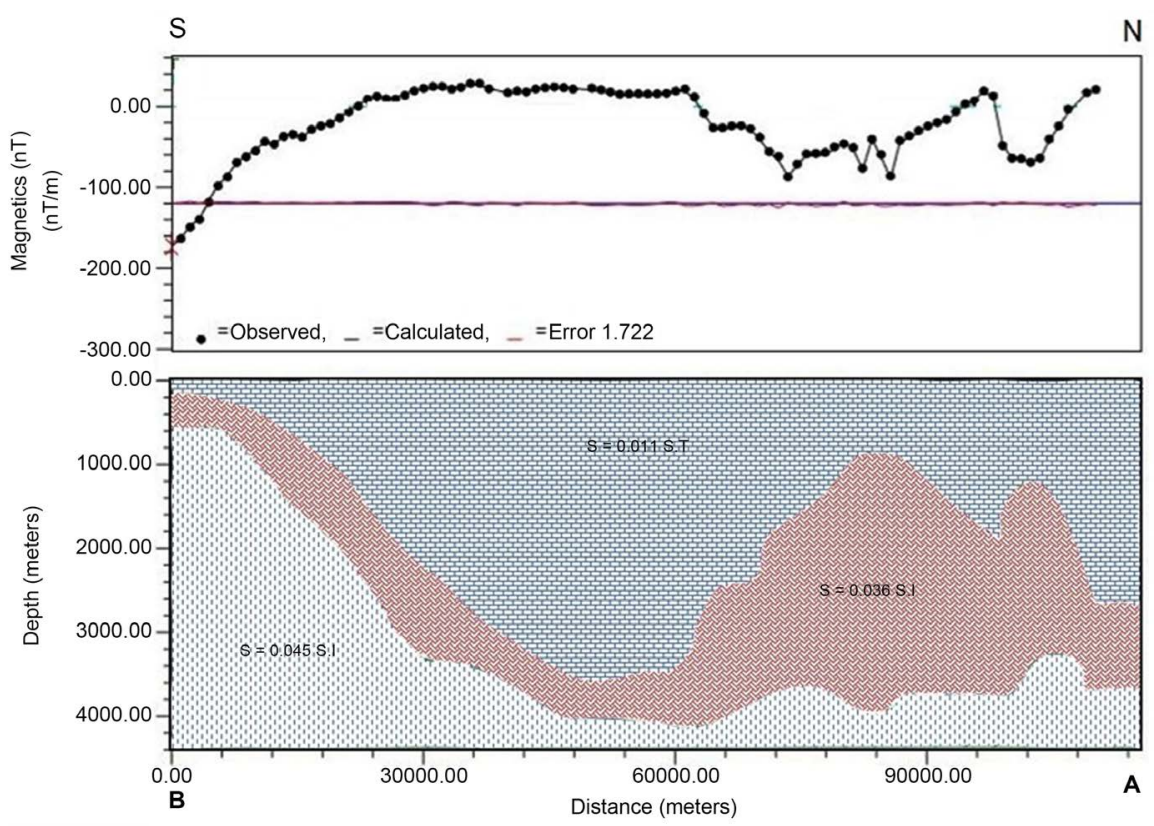

Figure 11. 2-D magnetic modeling along profile A-B in the N-S direction. 
depths and compositions, with different anomalies of varying frequencies and amplitudes. The tilt angle derivative (TDR) was used to locate the edges of this TMI-RTE. Positive values should be located above the magnetic sources while negative values are located away from them. The half distance between $\pm \pi / 4$ $( \pm 0.785)$ Radian was used to calculate the depth to these edges. By applying [43] method, the depth of basement surface reaches to $3000 \mathrm{~m}$ in the south-west and eastern parts of the study area, while it reaches $227 \mathrm{~m}$ in the north and western parts. The total horizontal derivative of the tilt derivative map (THDR_TDR) shows these edges as sharper and its values are the reciprocal of the depth to these contacts. The deduced average depths above them range from 380 to about $2800 \mathrm{~m}$. Euler deconvolution is applied to illustrate the distribution of contacts or faults and to estimate their depths which range from 245.24 to $2273.68 \mathrm{~m}$. Accordingly, the constructed interpretative structural map of study area is configured by a set of these contacts or faults which oriented in E-W, NE-SW and ENE-WSW, directions. The present results of trends agree with gravity studies in adjacent areas which highlight a reseau of faults-oriented $\mathrm{W}-\mathrm{E}$, and the audiomagnetotelluric data analysis that puts in evidence a secondary fault line with NE-SW general trend [43]. The orientation of the basement geological structures inferred from the magnetic maps suggests that they are products of the Brasiliano/Pan-African orogeny. Two main techniques were used to calculate the depth to the magnetic basement sources. AS and SPI were used to calculate the depth to the magnetic basement sources. They reflected similar results for estimating the basement depths. For both, the depth ranges from 150 to $2800 \mathrm{~m}$. The 2-D modeling tool was used for the data profile modeling, where more than one anomaly is considered in the process. The models indicate that, the granitic basement rocks range between $550 \mathrm{~m}$ and $4100 \mathrm{~m}$. Finally, the methods used in this study (TDR, THDR_TDR, 3-ED, AS and SPI) gave us similar results to the depth of the basement rocks, ranging in depth between 150 and $3000 \mathrm{~m}$ as the average range.

\section{Conflict of Interest}

The authors declare that there is no conflict of interests regarding the publication of this paper.

\section{Acknowledgements}

This work was carried out at the University of Yaoundé I, Cameroon, as part of first author's Ph.D. studies. The authors are thankful to the anonymous reviewers for their thorough comments which enabled to improve the initial version of this paper.

\section{References}

[1] Grant, F.S. (1985) Aeromagnetics, Geology and Ore Environments, I. Magnetite in Igneous, Sedimentary and Metamorphic Rocks: An Overview. Geoexploration, 23, 
303-333. https://doi.org/10.1016/0016-7142(85)90001-8

[2] Ogunmola, J.K., Ayolabi, E.A. and Olobaniyi, S.B. (2016) Structural-Depth Analysis of the Yola Arm of the Upper Benue Trough of Nigeria Using High Resolution Aeromagnetic Data. Journal of African Earth Sciences, 124, 32-43. https://doi.org/10.1016/j.jafrearsci.2016.09.008

[3] Adetona, A., Abbass and Mallam, A. (2013) Estimating the Thickness of Sedimentation within Lower Benue Basin and Upper Anambra Basin, Nigeria, Using Both Spectral Depth Determination and Source Parameter Imaging. International Journal of Geophysics, 20, Article ID: 124706.

[4] Paterson, Grant, Watson Ltd. (1976) Etudes aéromagnétiques sur certaines Régions de la République Unie du Cameroun. Rapport d'interprétation. ACDI, Toronto, 190 p.

[5] Noutchogwe, C., Tabod, C. and Manguelle-Dicoum, E. (2006) A Gravity Study of the Crust beneath the Adamawa Fault Zone, West Central Africa. Journal of Geophysics and Engineering, 3, 82-89. https://doi.org/10.1088/1742-2132/3/1/009

[6] Ndougsa-Mbarga, T., Meying, A., Bisso, D., Sharma, K.K., Layu, D.Y. and Manguelle-Dicoum, E. (2011) Audiomagnetotelluric (AMT) Soundings Based on the Bostick Approach and Evidence of Tectonic Features along the Northern Edge of the Congo Craton, in the Messamena/Abong-Mbang. Journal of Indian Geophysical Union, 15, 145-159.

[7] Ndougsa-Mbarga, T., Yufenyiu Layu, D., Quentin Yene-Atangana, J. and TabodTabod, C. (2014) Delineation of the Northern Limit of the Congo Craton Based on Spectral Analysis and 2.5D Modeling of Aeromagnetic Data in the Akonolinga-Mbama Area, Cameroon. Geofísica Internacional, 53, 5-16.

[8] Feumoe, A.N.S., Ndougsa-Mbarga, T., Manguelle-Dicoum, E. and Derek Fairhead, J. (2012) Delineation of Tectonic Lineaments Using Aeromagnetic Data for the South-East Cameroon Area. Geofizika, 29, 33-50.

[9] Bikoro-Bi-Alou, M., Ndougsa-Mbarga, T. and Tabod, T.C. (2014) Quantitative Interpretation of Magnetic Anomalies in Ebolowa-Djoum Area (Southern Cameroon). Geophysica, 50, 11-25.

[10] Ngoh, J.D., Ndougsa Mbarga, T., Assembe, S.P., Meying, A., Owono Amougou, O.U.I. and Tabod, C.T. (2017) Evidence of Structural Facts Inferred from Aeromagnetic Data Analysis over the Guider-Maroua Area (Northern Cameroon). International Journal of Geosciences, 8, 781-800.

https://doi.org/10.4236/ijg.2017.86044

[11] Yandjimain, J., Ndougsa-Mbarga, T., Meying, A., Bi-Alou, M.B., Ngoumou, P.C., Assembe, S.P., Ngoh, J.D. and Owono-Amougou, O.U.I. (2017) Combination of Tilt-Angle and Euler Deconvolution Approaches to Determine Structural Features from Aeromagnetic Data Modeling over Akonolinga-Loum Area (Centre-East, Cameroon). International Journal of Geosciences, 8, 925-947.

https://doi.org/10.4236/ijg.2017.87053

[12] Paterson, N.R. and Reeves, C.V. (1985) Applications of Gravity and Magnetic Surveys: The State-of-the-Art in 1985. Geophysics, 50, 2558-2594.

https://doi.org/10.1190/1.1441884

[13] Ngako, V., Njongfang, E., Aka, T.F., Affaton, P. and Nnange, J.M. (2006) The North-South Paleozoic Trend of Alkaline Magmatism from Niger-Nigeria to Cameroon: Complex Interaction between Hotspots and Precambrian Faults. Journal of African Earth Sciences, 45, 241-256. https://doi.org/10.1016/j.jafrearsci.2006.03.003

[14] Maurizot, P., Abessolo, A., Feybesse, A., Johan, J.L. and Lecompte, P. (1986) Etude 
et prospection minière au Sud-Ouest Cameroun. Synthèse des travaux de 1978-1985, Rapport BRGM 85 CNRS 066, Orléans, 274 p.

[15] Toteu, S.F., Penaye, J. and Poudjom Djomani, Y. (2004) Geodynamic Evolution of the Pan-African Belt in Central Africa with Special Reference to Cameroon. Canadian Journal of Earth Sciences, 41, 73-85. https://doi.org/10.1139/e03-079

[16] Dumont, J.F. (1986) Identification par télédétection de l'accident de la Sanaga (Cameroun). Sa position dans le contexte des grands accidents d'Afrique centrale et de la limite nord du craton congolais. Géodynamique, 1, 13-19.

[17] Kennedy, W.Q. (1964) The Structural Differentiation of Africa in the Pan-African (500 m.y) Tectonic Episode. Research Institute of African Geology, University of Leeds, Leeds, 48.

[18] Oliveira, E.P., Toteu, S.F., Araujo, M.N.C., Carvalho, M.J., Nascimento, R.S., Bueno, J.F., Mc Naughton, N. and BasilicI, G. (2006) Geologic Correlation between the Neoproterozoic Sergipano Belt (NE Brazil) and the Yaoundé Belt (Cameroon, Africa). Journal of African Earth Sciences, 44, 470-478. https://doi.org/10.1016/j.jafrearsci.2005.11.014

[19] Boukéké, D.B. (1994) Structures crustales d'Afrique centrale déduites des anomalies gravimétriques et magnétiques: Le domaine précambrien de la république centrafricaine et du sud-Cameroun. Thèse de Doctorat, Université de Paris sud, Centre d'Orsay, 278.

[20] Ngako, V., Affaton, P. and Njonfang, E. (2008) Pan-African Tectonics in Northwestern Cameroon: Implication for History of Western Gondwana. Gondwana Research, 14, 509-522. https://doi.org/10.1016/j.gr.2008.02.002

[21] Owona, S., Schulz, B., Ratschbacher, L., Mvondo Ondoa, J., Ekodeck, G.E., Tchoua, M.F. and Affaton, P. (2011) Pan-African Metamorphic Evolution in the Southern Yaounde Group (Oubanguide Complex, Cameroon) as Revealed by EMP-Monazite Dating and Thermobarometry of Garnet Metapelites. Journal African Earth Sciences, 59, 125-139. https://doi.org/10.1016/j.jafrearsci.2010.09.003

[22] Castaing, C., Feybesse, J.L., Thieblemont, D., Triboulet, C. and Chevremont, P. (1994) Paleogeographical Reconstructions of the Pan-African/Brasiliano Orogen: Closure of an Oceanic Domain or Intracontinental Convergence between Major Blocks. Precambrian Research, 69, 327-344.

https://doi.org/10.1016/0301-9268(94)90095-7

[23] Njonfang, E., Ngako, V., Moreau, Ch., Affaton, P. and Diot, H. (2008) Restraining Bends in High Temperature Shear Zones: The "Central Cameroon Shear Zone", Central Africa. Journal African Earth Sciences, 52, 9-20. https://doi.org/10.1016/j.jafrearsci.2008.03.002

[24] Nzenti, J.P., Bertrand, S.M. and Macaudière. J. (1994) La Chaîne Panafricaine au Cameroun: Cherchons suture et modèle. 15è reunion des Sciences de la Terre, Nancy, $99 \mathrm{p}$.

[25] Nzenti, J.P., Kapajika, B., Wörner, G. and Lubala, T.R. (2006) Synkinematic Emplacement of Granitoids in a Pan-African Shear Zone in Central Cameroon. Journal African Earth Sciences, 45, 74-86.

https://doi.org/10.1016/j.jafrearsci.2006.01.005

[26] Kwékam, M., Liégeois, J.-P., Njonfang, E., Affaton, P., Hartmann, G. and Tchoua, F. (2010) Nature, Origin and Significance of the Fomopéa Pan-African High-K Calc-Alkaline Plutonic Complex in the Centraal African Fold Belt (Cameroon). Journal African Earth Sciences, 57, 79-95. https://doi.org/10.1016/j.jafrearsci.2009.07.012 
[27] Owona, S. (2008) Archaean, Eburnean and Pan-African Features and Relationships in Their Junction Zone in the South of Yaoundé (Cameroon). PhD Thesis, University of Douala, Douala, 232.

[28] Nzenti, J.P. (1998) Neoproterozoic Alkaline Meta-Igneous Rocks from the Pan-African North Equatorial Fold Belt (Yaounde, Cameroon) Biotites and Magnetite Rich Pyroxenites. Journal of African Earth Sciences, 26, 37-47. https://doi.org/10.1016/S0899-5362(97)00135-8

[29] Mvondo, H., Den-Brok, S.W.J. and Mvondo-Ondoa, J. (2003) Evidence for Symmetric Extension and Exhumation of the Yaoundé Nappe (Pan-African Fold Belt, Cameroon). Journal of African Earth Sciences, 36, 215-231. https://doi.org/10.1016/S0899-5362(03)00017-4

[30] Nzenti, J.P., Barbey, P., Macaudiere, J. and Soba, D. (1988) Origin and Evolution of the Late Precambrian High-Grade Yaoundé Gneisses (Cameroon). Precambrian Research, 38, 91-109. https://doi.org/10.1016/0301-9268(88)90086-1

[31] Mvondo, H., Owona, S., Mvondo-Ondoa, J., Essono, J. and Yene-Atangana, J.Q. (2007) Comment on U-Pb Dating of Plutonic Rocks Involved in the Nappe Tectonic in Southern Cameroon: Consequence for the Pan-African Orogenic Evolution of the Central African Fold Belt. Journal of African Earth Sciences, 44, 479-493.

[32] Rolin, P. (1982) Présence d'un chevauchement ductile majeur d'âge panafricain dans la partie centrale de la République Centrafricaine: Résultats préliminaires. Comptes Rendus de 1 Académie des Sciences, Série II, 315, 467-470.

[33] Abdelsalam, G.M., Liégeois, L. and Stern, R.J. (2002) The Saharan Metacraton. Journal African Earth Science, 34, 119-136. https://doi.org/10.1016/S0899-5362(02)00013-1

[34] Gazel, J. (1954) Carte géologique de reconnaissance du Cameroun. Feuille $\mathrm{N}^{\circ}$ : NB.33. S.O.E.030. Dressée et publiée par le Service des Mines du Cameroun.

[35] Gazel, J. (1955) Notice explicative sur la feuille Batouri-Ouest. Direction des Mines. Cameroun, Yaoundé, $44 \mathrm{p}$.

[36] Baranov, V. (1957) A New Method for Interpretation of Aeromagnetic Maps: Pseudo-Gravimetric. Geophysics, 22, 359-383. https://doi.org/10.1190/1.1438369

[37] Leu, L. (1982) Use of Reduction-to-the-Equator Process for Magnetic Data Interpretation. Geophysics, 47, 445.

[38] Geosoft Inc. (2012b) Oasis Montaj v7.2 Software (Standard Edition): Integrated Platform Software for Earth Exploration. Geosoft Inc., Toronto.

[39] Miller, H.G. and Singh, V. (1994) Potential Field Tilt a New Concept for Location of Potential Field Sources. Journal of Applied Geophysics, 32, 213-217. https://doi.org/10.1016/0926-9851(94)90022-1

[40] Dentith, M. (2011) Magnetic Methods, Airborne. In: Gupta, H.S., Ed., Encyclopedia of Solid Earth Geophysics, Vol. 1, Springer, Dordrecht, 761-766. https://doi.org/10.1007/978-90-481-8702-7_119

[41] Verduzco, B., Fairhead, J.D., Green, C.M. and MacKenzie, C. (2004) New Insights into Magnetic Derivatives for Structural Mapping. The Leading Edge, 23, 116-119. https://doi.org/10.1190/1.1651454

[42] Salem, A., Williams, S., Fairhead, D., Smith, R. and Ravat, D. (2008) Interpretation of Magnetic Data Using Tilt-Angle Derivatives. Geophysics, 73, 1-10. https://doi.org/10.1190/1.2799992

[43] Salem, A., William, S., Fairhead, D., Ravat, D. and Smith, R. (2007) Tilt-Depth Method: A Simple Depth Estimation Method Using First-Order Magnetic Derivatives. 
The Leading-Edge, 150, 2-5. https://doi.org/10.1190/1.2821934

[44] Hinze, W.J., Von Frese, R.R.B. and Saad, A.H. (2013) Gravity and Magnetic Exploration Principles, Practices, and Applications. Cambridge University Press, New York, 515 p. https://doi.org/10.1017/CBO9780511843129

[45] Oruc, B. (2010) Edge Detection and Depth Estimation Using a Tilt Angle Map from Gravity Gradient Data of the Kozakl-Central Anatolia Region, Turkey. Pure and Applied Geophysics, 168, 1769-1780. https://doi.org/10.1007/s00024-010-0211-0

[46] Rahman, M. and Ullah, S.E. (2013) Constrained Interpretation of Aeromagnetic Data Using Tilt-Angle Derivatives from North-Western Part of Bangladesh. Global Advanced Research Journals, 2, 196-204.

[47] Nabighian, M.N. (1972) The Analytic Signal of Two-Dimensional Magnetic Bodies with Polygonal Cross-Section: Its Properties and Use for Automated Anomaly Interpretation. Geophysics, 37, 507-517. https://doi.org/10.1190/1.1440276

[48] Nabighian, M.N. (1974) Additional Comments on the Analytic Signal of Two Dimensional Magnetic Bodies with Polygonal Cross-Section. Geophysics, 39, 85-92. https://doi.org/10.1190/1.1440416

[49] Roest, W.R., Verhoef, J. and Pilkigton, M. (1992) Magnetic Interpretation Using the 3-D Signal Analytic. Geophysics, 57, 116-125. https://doi.org/10.1190/1.1443174

[50] Reid, A.B., Allsop, J.M., Granser, H., Millett, A.J. and Somerton, I.W. (1990) Magnetic Interpretation in Three Dimensions Using Euler Deconvolution. Geophysics, 55, 80-90. https://doi.org/10.1190/1.1442774

[51] Thompson, D.T. (1973) Identification of Magnetic Source Types Using Equivalent Simple Models. Fall Annual AGU Meeting, San Francisco, 10-13 December 1973.

[52] Wilsher, W.A. (1987) A Structural Interpretation of the Witwatersrand Basin through the Application of Automated Depth Algorithms to Both Gravity and Aeromagnetic Data. M.Sc. Thesis, University of Witwatersrand, Johannesburg.

[53] Yaghoobian, A., Boustead, G.A. and Dobush, T.M. (1993) Object Delineation Using Euler's Momogeneity Equation: Location and Depth Determination of Buried Ferro-Metallic Bodies. Application of Geophysics to Engineering and Environmental Problems, San Diego, 613-632. https://doi.org/10.4133/1.2922042

[54] Mushayandebvu, M.F., Lesur, V., Reid, A.B. and Fairhead, J.D. (2004) Grid Euler Deconvolution with Constraints for 2D Structures. Geophysics, 69, 489-496. https://doi.org/10.1190/1.1707069

[55] Thompson, D.T. (1982) EULDPH: A New Technique for Making Computer Assisted Depth Estimates from Magnetic Data. Geophysics, 47, 31-37. https://doi.org/10.1190/1.1441278

[56] Pilkington, M., Abdoh, A. and Cowan, D.R. (1995) Pre-Mesozoic Structure of the Inner Moray Firth Basin: Constraints from Gravity and Magnetic Data. First Break, 13, 291-300. https://doi.org/10.3997/1365-2397.1995015

[57] Smith, R.S., Thurston, J.B., Dai, T.F. and MacLeod, I.N. (1998) iSPITM-The Improved Source Parameter Imaging Method. Geophysical Prospecting, 46, 141-151. https://doi.org/10.1046/j.1365-2478.1998.00084.x

[58] Nabighian, M.N. and Hansen, R.O. (2001) Unification of Euler and Werner Deconvolution in Three Dimensions via the Generalized Hilbert Transform. Geophysics, 66, 1805-1810. https://doi.org/10.1190/1.1487122

[59] Cooper, G.R.J. (2002) An Improved Algorithm for the Euler Deconvolution of Potential Field Data. The Leading Edge, 21, 1197-1198. https://doi.org/10.1190/1.1536132

[60] Reid, A.B. and Thurston, J.B. (2014) The Structural Index in Gravity and Magnetic 
Interpretation: Errors, Uses, and Abuses. Geophysics, 79, 61-66. https://doi.org/10.1190/geo2013-0235.1

[61] Reid, A.B., Ebbing, J.O. and Susan, S.J. (2014) Avoidable Euler Errors-The Use and Abuse of Euler Deconvolution Applied to Potential Fields. Geophysical Prospecting, 62, 1162-1168. https://doi.org/10.1111/1365-2478.12119

[62] Thurston, J.B. and Smith, R.S. (1997) Automatic Conversion of Magnetic Data to Depth, Dip, and Susceptibility Contrast Using the SPI ${ }^{\mathrm{TM}}$ Method. Geophysics, 62, 807-813. https://doi.org/10.1190/1.1444190

[63] Fairhead, J.D., Williams, S.E. and Flanagan, G. (2004) Testing Magnetic Local Wave Number Depth Estimation Methods Using a Complex 3D Test Model. SEG Technical Program Expanded Abstracts, 742-745.

[64] Rajaram, M. (2009) What's New in Interpretation of Magnetic Data? Geohorizons, 50-51.

[65] Li, X. (2006) Understanding 3D Analytic Signal Amplitude. Geophysics, 71, 13-16. https://doi.org/10.1190/1.2184367

[66] Olinga, J.B., Mpesse, J.E., Minyem, D., Ngako, V., Ndougsa-Mbarga, T. and Ekodeck, G.E. (2010) The Awaé-Ayos Strike-Slip Shear Zones (Southern-Cameroon) Geometry, Kinematics and Significance in the Late Pan African Tectonics. Neues Jahrbuch für Geologie und Paläontologie-Abhandlungen, 257, 1-11. https://doi.org/10.1127/0077-7749/2010/0042

[67] Kankeu, B., Greilingb, R.O. and Nzenti, J.P. (2009) Pan-African Strike-Slip Tectonics in Eastern Cameroon-Magnetic Fabrics (AMS) and Structure in the Lom Basin and Its Gneissic Basement. Precambrian Research, 174, 258-272. https://doi.org/10.1016/j.precamres.2009.08.001

[68] Ndougsa-Mbarga, T., Manguelle-Dicoum, E., Tabod, C.T. and Mbom-Abane, S. (2003) Modelisation d'anomalies gravimétriques dans la région de Mengueme-Akonolinga (Cameroun). Science, Technologie et Développement, 10, 67-74.

[69] Basseka, C.A., Shandini, Y. and Tadjou, J.M. (2011) Subsurface Structural Mapping Using Gravity Data of the Northern Edge of the Congo Craton, South Cameroun. Geofizika, 28, 229-245.

[70] Shandini, N.Y., Tadjou, J.M., Tabod, C.T. and Fairhead, J.D. (2010) Gravity Data Interpretation in the Northern Edge of the Congo Craton, South-Cameroon. Anuário do Instituto de Geociências, 33, 73-82.

[71] Shandini, N.Y. and Tadjou, J.M. (2012) Interpreting Gravity Anomalies in South Cameroon, Central Africa. Earth Sciences Research Journal, 16, 5-9.

[72] Phillips, J.D. (2000) Locating Magnetic Contacts: A Comparison of the Horizontal Gradient, Analytic Signal, and Local Wavenumber Methods. SEG Technical Program Expanded Abstracts, 402-405. https://doi.org/10.1190/1.1816078

[73] Won, I.J. and Bevis, M. (1987) Computing the Gravitational Magnetic Anomalies Due to a Polygon: Algorithm and FORTRAN Subroutines. Geophysics, 52, 232-238. https://doi.org/10.1190/1.1442298

[74] Rasmussen, R. and Pedersen, L.B. (1979) End Corrections in Potential Field Modeling. Geophysical Prospecting, 27, 749-760. https://doi.org/10.1111/j.1365-2478.1979.tb00994.x 